Palimpsest: Journal of Information and Library Science Vol 12, Issue 2, (2021), page 99-110

\title{
Analisis Perilaku Informasi Mahasiswa Universitas Lampung: Suatu Kajian pada Proses Penelusuran Koleksi Karya Ilmiah dan Koleksi Sirkulasi
}

\author{
Information Behavior Analysis of Lampung University Students: \\ Searching Process for Scientific Paper and Circulation Collections: \\ a Case Study
}

\author{
Sugiyanta*, Erni Fitriani** \\ Universitas Lampung \\ sugiyantampd@gmail.com, ernifitriani21@gmail.com
}

Received : $24^{\text {th }}$ October 2021; Revised : $1^{\text {th }}$ December 2021; Accepted $: 3^{\text {th }}$ December 2021

Available Online : $5^{\text {th }}$ December 2021; Published Regularly : $5^{\text {th }}$ December 2021

\begin{abstract}
Information and communication technology in its development has an effect on human life including social, economic, cultural aspects, and libraries as well. Libraries are required to provide up to date information in diverse forms. There are differences in information behavior of University Students of Lampung on searching collections of scientific paper and circulation collections. The aims of this research is finding out the information behavior of students of Lampung University in the process of searching collections of scientific works and circulation collections, and mention the similarities and regulations of information behavior in the search of collections of scientific works and searches of circulation collections. This research method use qualitative descriptive, with data collection techniques through questionnaires provide to 60 students, with data collection techniques through questionnaires given to 60 students, which are divided into two groups, namely 30 students who search the collection of scientific works and 30 students who search circulation collections, observed in January 2020, documentation data through circulation service activity reports and library studies. The results obtained are: in general, the behavior of information of students of Lampung University on the search of collections of scientific works includes: using a personal laptop to access on the link: digilib.unila.ac.id., log in, search the faculty, study programs, published years and titles of scientific paper, do the citation. The behavior of information in the process of tracing circulation collections includes: conducting a search of circulation collection through a computer provided by the University Library of Lampung, access on the link: opac.unila.ac.id (online catalog), write down the name of the author or the title of book, record the call number of the circulation collections of interest, to the circulation collection shelves, take circulation collections to read or borrow to take home. But there are also behavioral similarities of information in the process of disseminating information collection of scientific works and tracing circulation collections that are both the process of tracing done online and searching for information by writing the name of the author, title, or subject.
\end{abstract}

Keywords: information behavior, University Student of Lampung, scientific paper collections, circulation collections, University Library of Lampung

Abstrak 
Palimpsest: Journal of Information and Library Science Vol 12, Issue 2, (2021), page 100-110

Teknologi Informasi dan komunikasi dalam perkembangannya berpengaruh pada kehidupan manusia mencakup aspek sosial, ekonomi, budaya, termasuk perpustakaan. Perpustakaan dituntut untuk menyediakan informasi yang up to date dan dalam bentuk yang beragam. Perpustakaan sebagai penyedia informasi berupaya untuk memenuhi kebutuhan informasi melalui penyediaan koleksi cetak maupun digital. Terdapat perbedaan perilaku informasi mahasiswa Universitas Lampung pada proses penelusuran koleksi karya ilmiah dan koleksi sirkulasi. Tujuan penelitian ini untuk mengetahui perilaku informasi mahasiswa Universitas Lampung pada proses penelusuran koleksi karya ilmiah dan koleksi sirkulasi, dan menyebutkan persamaan dan perbedaan perilaku informasi pada penelusuran koleksi karya ilmiah dan penelusuran koleksi sirkulasi. Metode penelitian ini menggunakan deskriptif kualitatif, dengan teknik pengumpulan data melalui kuesioner yang diberikan kepada 60 orang mahasiswa, yang terbagi menjadi dua kelompok, yaitu 30 orang mahasiswa yang melakukan penelusuran koleksi karya ilmiah dan 30 orang mahasiswa yang melakukan penelusuran koleksi sirkulasi, melakukan observasi pada bulan Januari 2020, data dokumentasi melalui laporan kegiatan layanan sirkulasi dan dan studi pustaka melalui teori-teori yang berkaitan dengan objek penelitian ini. Hasil yang diperoleh adalah: pada umumnya perilaku informasi mahasiswa Universitas Lampung pada penelusuran koleksi karya ilmiah meliputi melakukan penenlusuran koleksi karya ilmiah menggunakan laptop pribadi, melakukan $\log$ in, melakukan akses pada link digilib.unila.ac.id., mencari karya ilmiah melalui nama fakultas, program studi, tahun terbit, judul, nama penulis atau subjek, melakukan sitasi. Perilaku informasi pada proses penelusuran koleksi sirkulasi meliputi melakukan penelusuran koleksi sirkulasi melalui komputer yang disediakan Perpustakaan Universitas Lampung, melakukan akses katalog online pada link opac.unila.ac.id., mencari koleksi melalui nama pengarang, judul atau subjek, mencatat nomor panggil koleksi sirkulasi, mengambil koleksi pada rak koleksi, membaca di ruang baca atau melakukan peminjaman koleksi untuk dibawa pulang. Tetapi ada juga persamaan perilaku informasi pada proses penelusuran informasi koleksi karya ilmiah dan penelusuran koleksi sirkulasi yaitu kedua proses penelusuran dilakukan secara online dan pencarian informasi dengan menuliskan nama pengarang, judul, atau subjek.

Kata kunci: perilaku informasi, mahasiswa, koleksi karya ilmiah, koleksi sirkulasi, Perpustakaan Universitas Lampung

\section{Pendahuluan}

Teknologi informasi dan komunikasi dalam perkembangannya berpengaruh pada kehidupan manusia mencakup aspek sosial, ekonomi, dan budaya, termasuk perpustakaan. Perpustakaan dituntut menyediakan sumber informasi yang up to date dan dalam bentuk yang beragam. Pemustaka, sebagai orientasi layanan perpustakaan, merupakan generasi native yang dalam kesehariannya sudah terbiasa dengan teknologi begitupun dalam hal mengakses informasi. Pada era ini informasi yang tersaji harus mudah diakses dan praktis dalam pemanfatannya. Perpustakaan sebagai penyedia sumber informasi terus berupaya untuk menyediakan informasi untuk memenuhi kebutuhan pemustaka. Pemustaka, baik itu individu maupun kelompok, memiliki perbedaan perilaku dalam mencari informasi. Hal ini terjadi dikarenakan setiap individu memiliki karakter dan kebutuhan akan informasi yang berbeda. Karakter individu merupakan neurotisme, ekstrover-introver, keterbukaan pada pengalaman, keterbukaan terhadap kesepakatan, dan sifat berhati-hati (Purwoko, 2008). Informasi yang disediakan perpustakaan selain tercetak juga dalam bentuk digital atau file. Koleksi cetak biasanya disajikan pada rak koleksi misalnya koleksi sirkulasi, koleksi referensi, koleksi jurnal ilmiah, terbitan pemerintah, dan lain-lain. Koleksi digital (file) direkam pada database dan dapat diakses pada link tertentu. Penelitian ini tentang analisis perilaku informasi mahasiswa Universitas Lampung dalam melakukan penelusuran koleksi karya ilmiah dan koleksi sirkulasi. 
Palimpsest: Journal of Information and Library Science Vol 12, Issue 2, (2021), page 101-110

Tujuan penelitian ini adalah untuk mengetahui perilaku informasi mahasiswa Universitas Lampung dalam penelusuran koleksi karya ilmiah dan koleksi sirkulasi dan menyebutkan perbedaan dan persamaan perilaku informasi mahasiswa dalam penelusuran koleksi karya ilmiah dan koleksi sirkulasi.

Pemakai perpustakaan dalam Online Dictionary of Library and Information Science adalah setiap orang yang menggunakan sumber daya dan pelayanan perpustakaan, meskipun tidak selalu terdaftar sebagai peminjam. Pemakai merupakan posisi yang penting dalam siklus kegiatan perpustakaan. Tolok ukur keberhasilan perpustakaan adalah dalam pemenuhan kebutuhan informasi pemakainya. Setiap individu memiliki karakter dan kebutuhan informasi yang berbeda. Perbedaan karakter mempengaruhi pada cara pencarian informasi yang berbeda juga. Purwoko (2008) dalam tulisannya menyebutkan bahwa, karakter individu akan membedakan dalam pencarian informasi. Karakter individu meliputi neurotisme, ekstrover-introver, keterbukaan pada pengalaman, keterbukaan terhadap kesepakatan, dan sifat berhati-hati. Kemudian Purwoko menyimpulkan bahwa setiap individu akan memakai cara yang berbeda dalam setiap pencarian informasi. Istilah perilaku informasi merupakan istilah dalam ilmu perpustakaan dan informasi. Perilaku adalah aktivitas menyeluruh dari individu atau kelompok baik subjektif maupun objektif sebagai umpan balik dari respon atau tanggapan. Tahun 2020 anggota perpustakaan Universitas Lampung berjumlah 45.942 yang terdiri dari 43.423 orang dari unsur mahasiswa, 1176 orang dari unsur dosen dan 1343 orang dari unsur tenaga kependidikan.

\section{Metode Penelitian}

Metode penelitian ini menggunakan deskriptif kualitatif yakni menganalisis dan mengkaji secara mendalam tentang perilaku informasi mahasiswa Universitas Lampung dalam proses penelusuran koleksi karya ilmiah dan koleksi sirkulasi. Teknik pengumpulan data melalui kuesioner pada 60 orang mahasiswa Universitas Lampung, yang dibagi menjadi dua kelompok, yaitu 30 orang Mahasiswa Universitas Lampung yang melakukan penelusuran koleksi karya ilmiah dan 30 orang Mahasiswa Universitas Lampung yang melakukan penelusuran koleksi sirkulasi. Observasi dilakukan pada bulan Januari tahun 2020, terhitung dari tanggal 3 sampai dengan 31 Januari 2020, data dokumentasi melalui laporan kegiatan UPT Perpustakaan Universitas Lampung dan studi pustaka melalui kutipan teori yang sesuai dengan objek penelitian ini.

\section{Hasil dan Diskusi}

Informasi adalah segala yang dikomunikasikan, baik secara lisan, tertulis, terekam, dan lain sebagainya. Informasi selalu berkaitan dengan pesan. Informasi yang terkandung dalam pesan dapat disamakan dengan pesan itu sendiri. Perilaku informasi dalam bidang ilmu perpustakaan memiliki beberapa makna. Pendit (1992) dalam Wilson menerjemahkan beberapa istilah perilaku informasi, yaitu

a. Perilaku informasi (information behavior) merupakan keseluruhan perilaku manusia berkaitan dengan sumber dan saluran informasi, termasuk perilaku pencarian dan penggunaan informasi baik secara aktif maupun pasif.

b. Perilaku pencarian informasi (information seeking behaviour), merupakan upaya menemukan informasi untuk tujuan tertentu. Perilaku ini terdiri dari berbagai bentuk 
c. Perilaku penggunaan informasi (information use behaviour), merupakan tindakan fisik maupun mental yang dilakukan seseorang ketika menggabungkan informasi yang ditemukannya dengan pengetahuan dasar yang sudah dimiliki.

\section{Pelayanan Perpustakaan}

Layanan informasi pemustaka merupakan bagian dari layanan perpustakaan. Pelayanan perpustakaan merupakan faktor utama dalam pengelolaan dan penyelenggaraan perpustakaan. Tolok ukur keberhasilan perpustakaan adalah dapat memenuhi kebutuhan informasi pemustaka.

Layanan perpustakaan dalam Undang-Undang Nomor 43 Tahun 2007 tentang Perpustakaan pasal 14 ayat (1), " layanan perpustakaan dilakukan secara prima dan berorientasi bagi kepentingan pemustaka". Dapat dikatakan bahwa layanan prima adalah layanan yang berorientasi pada kebutuhan informasi pemustaka, kemudahan dalam mengakses informasi, sumber daya informasi yang terkoneksi dengan database sumber daya informasi lokal dan nasional.

\section{Layanan Sirkulasi}

Layanan sirkulasi (circulation services) adalah layanan peminjaman dan pengembalian koleksi perpustakaan seperti buku dan koleksi perpustakaan lainnya, dengan jumlah dan kurun waktu tertentu (Perpustakaan Nasional, RI. 2015). Biasanya layanan sirkulasi menggunakan sistem layanan terbuka (open access), yaitu layanan yang memberi keleluasaan pada pemustaka untuk mencari secara langsung koleksi yang dinginkannya pada rak koleksi.

Layanan sirkulasi di Perpustakaan Universitas Lampung (Unila) memiliki syarat dan ketentuan sebagai berikut, 1) hanya anggota perpustakaan yang dapat meminjam buku dan 2) setiap anggota perpustakaan dapat meminjam buku sebanyak tiga (3) judul untuk masa peminjaman selama tujuh (7) hari dan dapat diperpanjang satu kali peminjaman selama tujuh (7) hari kemudian.

\section{Layanan Koleksi Karya Ilmiah}

Pelayanan koleksi karya ilmiah (scientific paper collections) merupakan layanan peminjaman dan pengembalian koleksi perpustakaan berupa tugas akhir, skripsi, tesis, dan disertasi hasil penelitian ilmiah civitas academica (Panduan Perpustakaan Unila, 2017). Koleksi karya ilmiah tersedia dalam bentuk tercetak yaitu karya ilmiah yang terbit tahun 2011 sampai dengan tahun 2014, sedangkan koleksi karya ilmiah dalam bentuk file (pdf) karya ilmiah yang terbit mulai tahun 2012 sampai dengan sekarang. Penelusuran karya ilmiah Universitas Lampung yang berbentuk file/digital dapat diakses secara full text untuk bab 1, 2, 3, dan bab kesimpulan. File tersebut dapat di-download melalui http://digilib.unila.ac.id.

Setiap orang akan melakukan pencarian dan penggunaan informasi untuk memenuhi kebutuhan informasinya. Dalam penelitian ini akan dibahas mengenai perilaku informasi mahasiswa Universitas Lampung pada penelusuran koleksi karya ilmiah dan koleksi sirkulasi. 


\section{Perilaku Informasi Mahasiswa Unila pada Penelusuran Koleksi Karya Ilmiah}

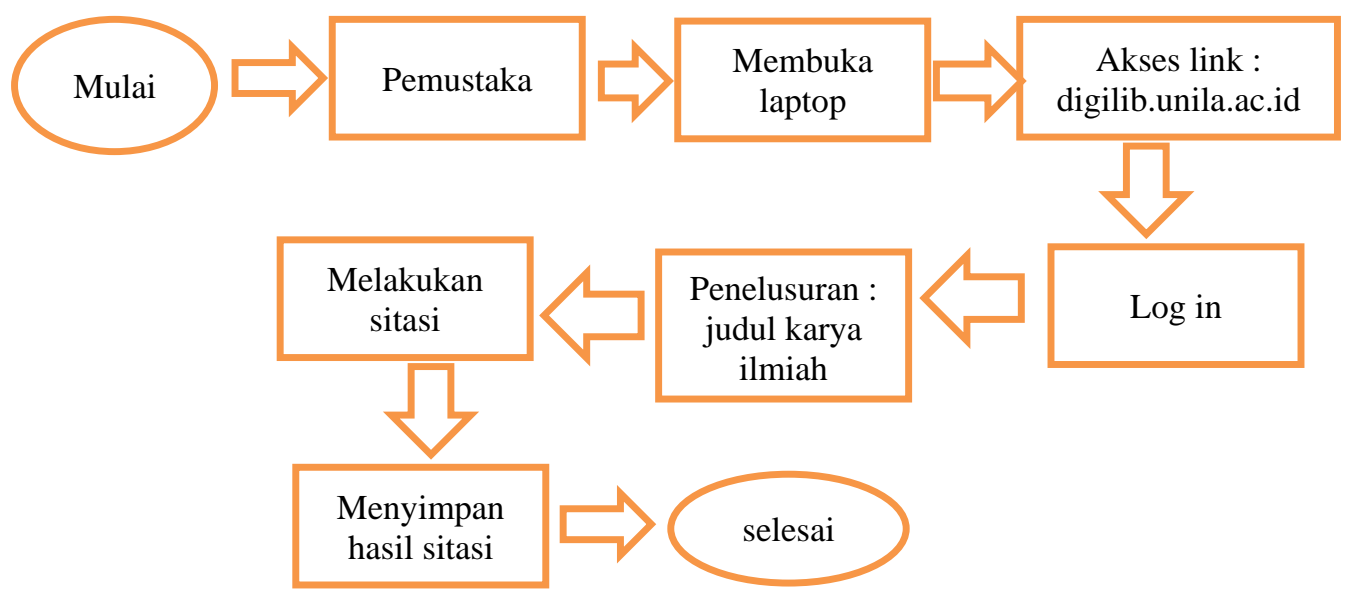

Gambar 1.

Alur penelusuran koleksi karya ilmiah

Gambar 1. Menunjukkan alur penelusuran koleksi karya ilmiah di Universitas Lampung dimulai dengan pemustaka membuka laptop pribadi, kemudian melakukan akses pada database koleksi karya ilmiah melalui link digilib.unila.ac.id, kemudian melakukan log in, melakukan pencarian melalui judul karya ilmiah yang diminati, melakukan sitasi dan menyimpan hasil sitasi pada file kerjanya, proses selesai.

\section{Perilaku Informasi Mahasiswa Universitas Lampung pada Penelusuran Koleksi Sirkulasi}

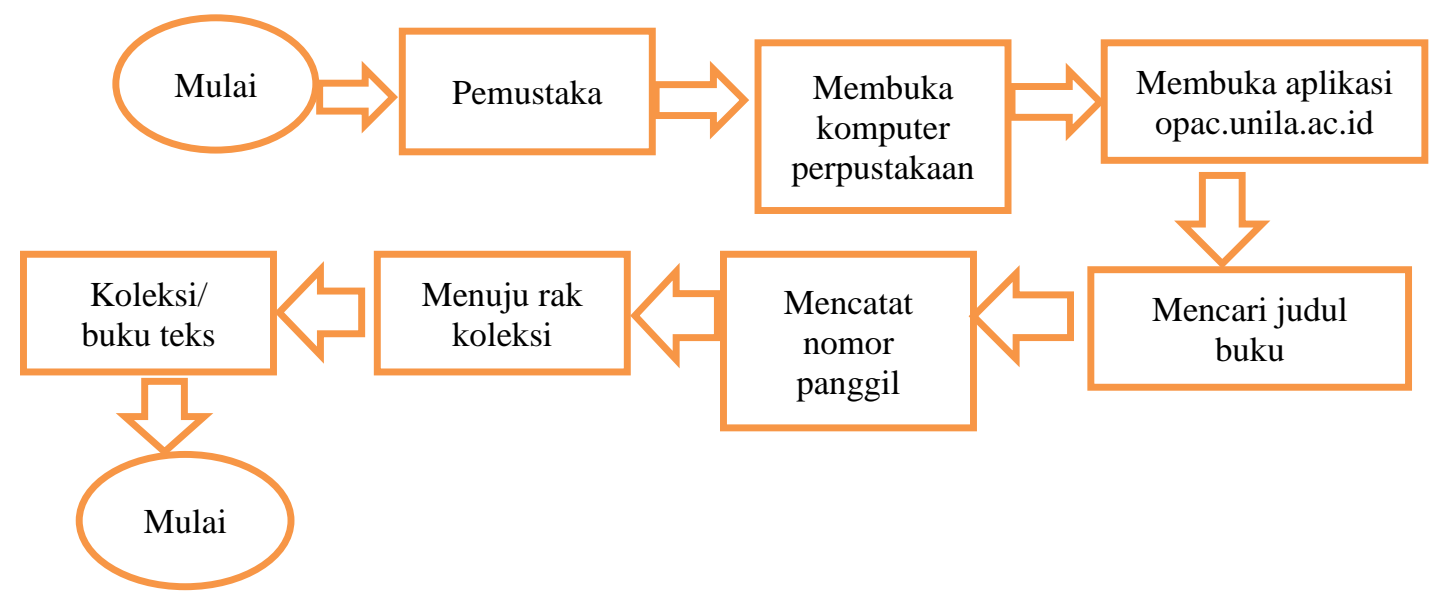

Gambar 2.

Alur penelusuran koleksi sirkulasi

Gambar 2. Menunjukkan alur penelusuran koleksi sirkulasi di Perpustakaan Unila, dimulai dengan pemustaka melakukan akses pada katalog online (opac.unila.ac.id) melalui komputer yang disediakan di lobby Perpustakaan Unila, melakukan pencarian koleksi sirkulasi melalui judul, nama pengarang, dan subjek koleksi, mencatat nomor panggil koleksi, kemudian 
Palimpsest: Journal of Information and Library Science Vol 12, Issue 2, (2021), page 104-110

Tabel 1.

Perilaku penelusuran koleksi karya ilmiah dan koleksi sirkulasi mahasiswa Unila

\begin{tabular}{|c|c|c|c|c|c|}
\hline \multirow[t]{2}{*}{ No } & \multirow[t]{2}{*}{ Perilaku Informasi } & \multicolumn{2}{|c|}{$\begin{array}{c}\text { Jumlah Responen } \\
\text { pada penelusuran Koleksi } \\
\text { karya ilmiah }\end{array}$} & \multicolumn{2}{|c|}{$\begin{array}{c}\text { Jumlah Responeden pada } \\
\text { penelusuran koleksi } \\
\text { sirkulasi }\end{array}$} \\
\hline & & Ya & Tidak & Ya & Tidak \\
\hline 1 & Melakukan $\log$ in & 30 & 0 & 0 & 0 \\
\hline 2 & $\begin{array}{l}\text { Melakukan akses melalui } \\
\text { laptop pribadi }\end{array}$ & 30 & 0 & 0 & 30 \\
\hline 3 & $\begin{array}{l}\text { Melakukan akses pada link } \\
\text { digilib.unila.ac.id. }\end{array}$ & 30 & 0 & 0 & 30 \\
\hline 4 & $\begin{array}{l}\text { Melakukan pencarian melalui } \\
\text { nama pengarang, judul, atau } \\
\text { subjek }\end{array}$ & 30 & 0 & 30 & 0 \\
\hline 5 & Melakukan sitasi & 30 & 0 & 0 & 0 \\
\hline 6 & $\begin{array}{l}\text { Menggunakan komputer yang } \\
\text { tersedia di Perpustakaan } \\
\text { Unila }\end{array}$ & 0 & 0 & 30 & 0 \\
\hline 7 & $\begin{array}{l}\text { Akses pada aplikasi } \\
\text { opac.unila.ac.id }\end{array}$ & 0 & 0 & 30 & 0 \\
\hline 8 & Mencatat nomor panggil & 0 & 0 & 30 & 0 \\
\hline 9 & $\begin{array}{l}\text { Mencari koleksi secara } \\
\text { langsung ke rak koleksi }\end{array}$ & 0 & 30 & 30 & 0 \\
\hline 10 & $\begin{array}{l}\text { Mengambil koleksi pada rak } \\
\text { layanan }\end{array}$ & 0 & 0 & 30 & 0 \\
\hline 11 & $\begin{array}{l}\text { Membaca di ruang baca atau } \\
\text { melakukan peminjaman } \\
\text { koleksi }\end{array}$ & 30 & 0 & 30 & 0 \\
\hline
\end{tabular}

Sumber: Hasil oleh data analisis perilaku informasi penelusuran koleksi karya ilmiah dan koleksi sirkulasi, 2020

Tabel 1. Menunjukkan bahwa semua responden sebanyak 30 mahasiswa dalam melakukan penelusuran koleksi karya ilmiah dengan menggunakan laptop pribadi, kemudian melakukan akses pada link digilib.unila.ac.id, kemudian melakukan pencarian koleksi melalui nama pengarang, judul, dan subjek, dilanjutkan dengan membuat sitasi dan menyimpannya pada file pribadi sebagai data untuk penelitiannya. Sebanyak 30 orang pemustaka dalam penelusuran koleksi sirkulasi melakukan penelusuran melalui komputer yang tersedia di lobby perpustakaan, melakukan akses melalui link opac.unila.ac.id, kemudian mencatat nomor panggil koleksi sirkulasi, kemudian mencari koleksi secara langsung pada rak koleksi, kemudian mengambil koleksi sirkulasi untuk dibaca di ruang baca atau dipinjam untuk dibawa pulang.

Data pada tabel 1 menunjukkan adaya persamaan dan perbedaan pada perilaku informasi penelusuran koleksi karya ilmiah dan penelusuran koleksi sirkulasi. Persamaan perilaku informasi pada penelusuran koleksi karya ilmiah dan koleksi sirkulasi adalah 
1. Penelusuran dilakukan secara online

2. Melakukan penelusuran pada aplikasi dengan menuliskan nama pengaranag, judul atau subjek pada kolom pencarian.

Perbedaan perilaku informasi pada penelusuran koleksi karya ilmiah dan penelusuran koleksi sirkulasi disajikan pada tabel 2 di bawah ini,

Tabel 2.

Perbedaan perilaku informasi pada penelusuran koleksi karya ilmiah dan koleksi

$\begin{array}{cc}\begin{array}{c}\text { Perilaku informasi pada penelusuran koleksi } \\ \text { karya ilmiah }\end{array} & \begin{array}{c}\text { Perilaku informasi pada penelusuran koleksi } \\ \text { sirkulasi }\end{array}\end{array}$

- Menggunakan laptop pribadi

- Melakukan $\log$ in

- Akses pada aplikasi digital.library,unila.ac.id

- Melakukan sitasi

- Menyimpan hasil sitasi pada file
- Menggunakan komputer yang tersedia di perpustakaan (lobby perpustakaan)

- Akses pada aplikasi opac.unila.ac.id

- Mencatat nomor panggil

- Mencari koleksi secara langsung ke rak koleksi

- Mengambil koleksi pada rak layanan

- Membaca di ruang baca atau melakukan peminjaman koleksi

Sumber: Layanan Pemustaka Perpustakaan Unila, 2020

\section{Anggota Perpustakaan}

Anggota perpustakaan Unila adalah civitas academica Unila meliputi mahasiswa, dosen, dan tenaga kependidikan yang berstatus aktif di Unila. Sistem otomasi Perpustakaan Unila telah terintegrasi dengan data kemahasiswaan dan kepegawaian, sehingga untuk setiap penambahan jumlah mahasiswa baru, dosen dan tenaga kependidikan, akan secara otomatis juga terdaftar dan menjadi anggota Perpustakaan. Berbeda halnya dengan pemustaka dari luar Unila yang ingin mendaftar menjadi anggota Perpustakaan Unila, mereka harus terlebih dahulu mendaftarkan diri di bagian administrasi Perpustakaan Unila. Rincian jumlah anggota Perpustakaan Universitas Lampung dapat dilihat pada tabel 3 berikut ini,

Tabel 3.

Anggota Perpustakaan Unila unsur mahasiswa

\begin{tabular}{cccc}
\hline \multicolumn{3}{c}{ Jumlah Mahasiswa yang menjadi } & Anggota Perpustakaan 3 Tahun terakhir \\
\hline \multirow{2}{*}{ Fakultas } & \multicolumn{3}{c}{ Tahun Akademik } \\
\cline { 2 - 4 } & $\mathbf{2 0 1 8}$ & $\mathbf{2 0 1 9}$ & $\mathbf{2 0 2 0}$ \\
\hline Fakultas Ekonomi & 4169 & 4640 & 4969 \\
dan Bisnis & & & \\
Fakultas Hukum & 2959 & 3483 & 4021 \\
Fakultas Keguruan & 7908 & 9423 & 10747 \\
dan Ilmu Pendidikan & & & \\
Fakultas pertanian & 5055 & 6089 & 7034 \\
Fakultas teknik & 3888 & 4552 & 5380 \\
\hline
\end{tabular}


Palimpsest: Journal of Information and Library Science Vol 12, Issue 2, (2021), page 106-110

\begin{tabular}{cccc}
\hline \multicolumn{3}{c}{ Jumlah Mahasiswa yang menjadi } & Anggota Perpustakaan 3 Tahun terakhir \\
\hline \multicolumn{3}{c}{ Fakultas } & \multicolumn{3}{c}{ Tahun Akademik } \\
\cline { 2 - 4 } & $\mathbf{2 0 1 8}$ & $\mathbf{2 0 1 8}$ & $\mathbf{2 0 1 8}$ \\
\hline Fakultas Ilmu Sosial & 4245 & 4909 & 5487 \\
dan Ilmu Politik & & & \\
Fakultas Mipa & 3335 & 3915 & 4498 \\
Fakultas Kedokteran & 847 & 1089 & 1287 \\
Pasca Sarjana & 54 & 629 & - \\
\hline Jumlah anggota & $\mathbf{3 2 . 4 6 0 ( 1 0 0 \% )}$ & $\mathbf{3 8 . 7 2 9}(\mathbf{1 0 0 \% )}$ & $\mathbf{4 3 . 4 2 3 ( 1 0 0 \% )}$
\end{tabular}

Sumber: Buku Unila dalam Angka 2018, 2019, dan 2020

Tabel 3. Menunjukkan bahwa semua mahasiswa Universitas Lampung menjadi anggota potensial Perpustakaan Unila, dalam tiga tahun terakhir jumlah anggota Perpustakaan Unila mengalami peningkatan. Tahun 2018 mahasiswa yang menjadi anggota perpustakaan sebanyak 32.460 orang, tahun 2019 mahasiswa yang menjadi anggota perpustakaan sebanyak 38.729 , terdapat peningkatan jumlah anggota sebanyak 6269 orang atau 0,19\%, tahun 2020 jumlah mahasiswa yang menjadi anggota perpustakaan sebanyak 43.423 orang, terdapat peningkatan jumlah anggota perpustakaan sebanyak 4694 atau sebesar 0,12\%. Peningkatan tersebut dikarenakan adanya penambahan beberapa program studi baru yang dibuka di Universitas Lampung.

Tabel 4.

Anggota perpustakaan Unila unsur dosen dan tenaga kependidikan

\begin{tabular}{lccc}
\hline \multicolumn{3}{c}{ Data Dosen dan Tenaga Kependidikan Unila yang menjadi Anggota } \\
& \multicolumn{3}{c}{ Terpustakaan Unila } \\
\hline \multirow{2}{*}{ Status } & $\mathbf{2 0 1 8}$ & $\mathbf{2 0 1 9}$ & $\mathbf{2 0 2 0}$ \\
\cline { 2 - 4 } & 1308 & 1374 & 1176 \\
\hline Dosen & 1259 & 1415 & 1343 \\
Tenaga/Kependidikan & & & $2.519(100 \%)$ \\
\hline Jumlah anggota & $2.567(100 \%)$ & $2.789(100 \%)$ & \\
\hline
\end{tabular}

Sumber: Buku Laporan Rektor Tahun 2019/2020 dan Kepegawaian Unila 2020

Tabel 4. Menunjukkan bahwa dosen dan tenaga kependidikan di Universitas Lampung $100 \%$ menjadi anggota potensial Perpustakaan Unila.

\section{Koleksi Perpustakaan}

Koleksi perpustakaan adalah semua informasi dalam bentuk karya tulis, karya cetak, dan atau karya rekam dalam berbagai media yang mempunyai nilai pendidikan, yang dihimpun, diolah dan dilayankan. Jenis koleksi Perpustakaan Unila terdiri dari buku cetak, buku elektronik (e-book), jurnal, e-journal, karya ilmiah mahasiswa dan dosen dalam bentuk cetak dan elektronik. Selain itu juga terdapat koleksi CD-ROM dan koleksi rujukan. Koleksi diperoleh dengan cara pembelian, berlangganan, hibah, atau hadiah dari berbagai sumber. Subyek koleksi dikelompokkan berdasarkan klasifikasi Dewey Decimal Classification (DDC) 21 meliputi karya 
Palimpsest: Journal of Information and Library Science Vol 12, Issue 2, (2021), page 107-110

umum, filsafat, agama, sosial, bahasa, ilmu murni, ilmu terapan, kesusastraan , kesenian, dan sejarah.

Dalam mewujudkan layanan prima bagi pemustaka, UPT Perpustakaan Unila menyediakan berbagai jenis koleksi yang tercetak maupun digital, tersaji pada tabel 5 di bawah ini

Tabel 5.

Koleksi buku teks dan koleksi karya ilmiah Perpustakaan Unila

\begin{tabular}{|c|c|c|c|c|c|c|c|}
\hline \multirow{3}{*}{ No. } & \multirow{3}{*}{ Jenis Koleksi } & \multicolumn{6}{|c|}{ Tahun } \\
\hline & & \multicolumn{2}{|c|}{2018} & \multicolumn{2}{|c|}{2019} & \multicolumn{2}{|c|}{2020} \\
\hline & & Judul & Eks & Judul & Eks & Judul & Eks \\
\hline \multirow[t]{5}{*}{ A. } & Buku & & & & & & \\
\hline & 1. Buku (Tercetak) & 28.022 & 158.214 & 28.787 & 159.377 & 28.803 & 159.345 \\
\hline & $\begin{array}{l}\text { 2. Elektronik Buku } \\
\text { (Lokal akses) }\end{array}$ & 562 & 562 & 1.090 & 1.090 & 1.090 & 1.090 \\
\hline & $\begin{array}{l}\text { 3. Elektronik Buku } \\
\text { (Pembelian) }\end{array}$ & 151 & 151 & 452 & 1.904 & 1.311 & 3.622 \\
\hline & Jumlah & 28.735 & 158.927 & 30.329 & 162.371 & 31.204 & 164.057 \\
\hline \multirow[t]{3}{*}{ B. } & Skripsi & & & & & & \\
\hline & Skripsi Digital & 22.537 & 22.537 & 28.102 & 28.102 & 31.623 & 31.623 \\
\hline & Jumlah & 22.537 & 22.537 & 28.102 & 28.102 & 31.623 & 31.623 \\
\hline \multirow[t]{4}{*}{ C. } & Tesis & & & & & & \\
\hline & 1. Tesis Digital & 3.641 & 3.641 & 4.315 & 4.315 & 4.784 & 4.784 \\
\hline & 2. Disertasi Digital & 0 & 0 & 14 & 14 & 25 & 25 \\
\hline & Jumlah & 3.641 & 3.641 & 4329 & 4329 & 4809 & 4809 \\
\hline
\end{tabular}

Sumber: Dokumen Akreditasi Perpustakaan Unila, 2020

Koleksi buku teks diperoleh dengan cara pembelian dan hibah hasil kerja sama dengan lembaga pemerintah maupun perorangan. Sementara itu untuk koleksi buku elektronik diperoleh melalui pembelian atau berlangganan. Koleksi karya ilmiah diperoleh dari mahasiswa Universitas Lampung strata-1 (S1), strata-2 (S2) dan strata-3 (S3) yang telah menyelesaikan masa studinya di Unila.

\section{Layanan Perpustakaan}

UPT Perpustakaan Universitas Lampung memiliki dua jenis layanan berdasarkan interaksinya yaitu layanan teknis dan layanan pengunjung. Layanan pengunjung diantaranya adalah

a. Layanan katalog online (OPAC)

Layanan katalog online merupakan layanan alat bantu penelusuran secara digital untuk mencari koleksi buku cetak dan koleksi karya ilmiah mahasiswa Unila yang dimiliki Perpustakaan Unila. Layanan katalog online untuk buku cetak dapat diakses melalui link http://opac.unila.ac.id., untuk koleksi karya ilmiah (skripsi, tesis, disertasi, dan laporan akhir) dapat diakses melalui link http://opac.unila.ac.id/kki untuk karya ilmiah (skipsi, tesis, tugas akhir, dan laporan akhir). 
Palimpsest: Journal of Information and Library Science Vol 12, Issue 2, (2021), page 108-110

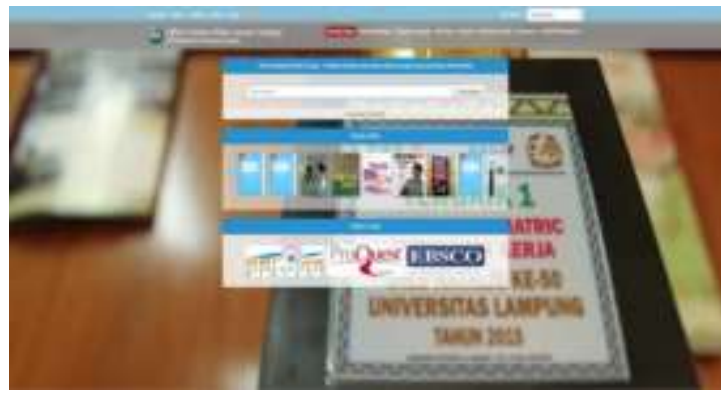

Gambar 3.

Katalog online Perpustakaan Unila

Langkah-langkah pemanfaatan katalog online adalah sebagai berikut,

a) Pemustaka menuju komputer penelusuran koleksi

b) Menuliskan judul buku atau nama pengarang pada kolom pencarian kemudian tekan enter

c) Untuk pencarian koleksi yang spesifik, pemustaka menuliskan identitas buku secara rinci meliputi: nama pengarang, subyek, ISBN atau ISSN, GMD, tipe koleksi, maupun lokasi. Seperti tertera pada gambar 4

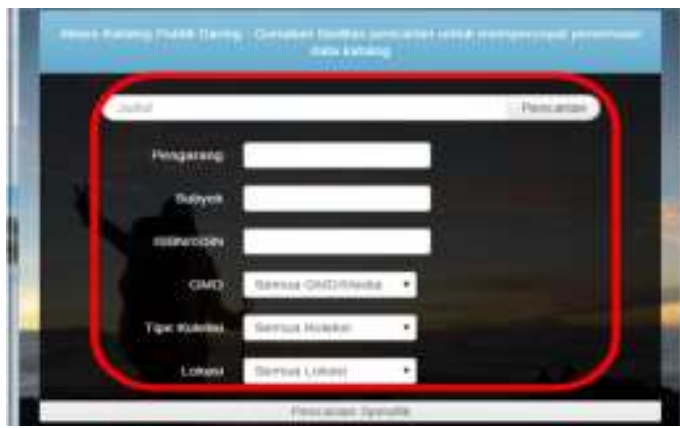

Gambar 4.

Rincian pencarian spesifik

d) Keterangan pada label buku

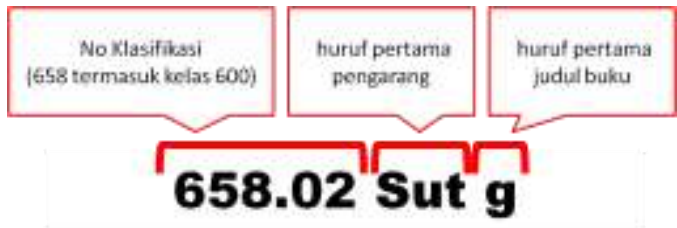

Gambar 5.

Keterangan label buku

b. Layanan koleksi karya ilmiah Universitas Lampung

Digital repository Unila merupakan layanan penelusuran koleksi karya ilmiah (KKI) mahasiswa Unila seperti skripsi, tesis, disertasi, tugas akhir, dan laporan akhir dengan alamat link http://digilib.unila.ac.id. Layanan ini dapat diakses secara online dan full text untuk file bab 1, 2, 3, dan bab kesimpulan, sementara untuk file bab pembahasan hanya dapat dibaca saja. 


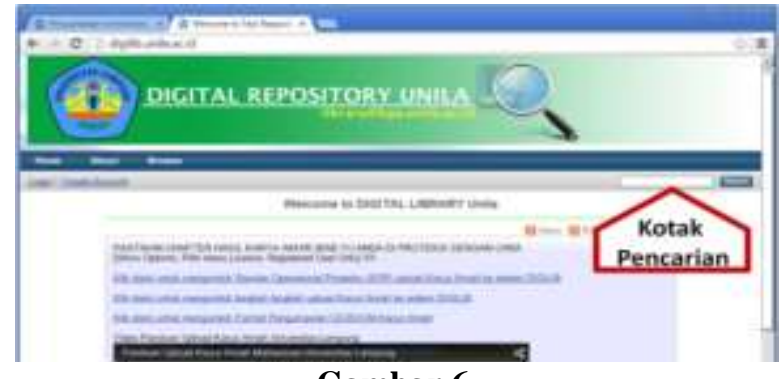

Gambar 6.

Kotak pencarian

Gambar 6 menunjukkan tampilan menu digital repository KKI Unila, penelusuran dapat dilakukan melalui nama pengarang, judul, dan subjek karya ilmiah. Untuk membaca secara fulltext, klik preview pada dokumen tersebut.

\section{Kesimpulan}

Berdasarkan hasil olah data pada 60 orang mahasiswa yang terbagi menjadi dua kelompok yaitu 30 orang mahasiswa yang melakukan penelusuran koleksi karya ilmiah dan 30 orang mahasiswa yang melakukan penelusuran koleksi sirkulasi adalah pada umumnya mahasiswa yang melakukan penelusuran informasi penelusuran koleksi karya ilmiah menunjukkan perilaku informasi meliputi menggunakan laptop pribadi, melakukan log in, melakukan akses pada link digilib.unila.ac.id, melakukan penelusuran dengan menuliskan nama pengarang, judul atau subjek pada kolom pencarian, melakukan sitasi, dan menyimpan hasil sitasi pada file pribadi. Perilaku informasi mahasiswa pada penelusuran koleksi sirkulasi meliputi melakukan akses pada komputer yang disediakan di lobby perpustakaan, melakukan pencarian koleksi melalui katalog online (opac.unila.ac.id) dengan menuliskan nama pengarang, judul atau subjek pada kolom pencarian, mencatat nomor panggil koleksi, kemudian mengambil koleksi sirkulasi pada rak layanan, membaca di ruang baca atau melakukan peminjaman koleksi sirkulasi untuk dibawa pulang. Biasanya mahasiswa yang melakukan penelusuran koleksi karya ilmiah sebagai bahan referensi untuk penelitian, sedangkan mahasiswa yang melakukan penelusuran koleksi sirkulasi biasanya sebagai bahan untuk mengerjakan tugas perkuliahan dan untuk menambah wawasan. Adapun persamaannya adalah perilaku informasi pada penelusuran koleksi karya ilmiah dan koleksi sirkulasi keduanya dilakukan secara online dan proses penelusuran koleksi dengan menuliskan nama pengarang, judul, atau subjek pada kolom pencarian.

\section{Daftar Pustaka}

Layanan Koleksi Karya Ilmiah (2010). Dikutip dalam library.ums.ac.id. Diakses tanggal 05 Januari 2020

Pendit, Putu Laxman (1992) Makna Informasi: Lanjutan Dari Sebuah Perdebatan. Dalam Kepustakawanan Indonesia: Potensi dan Tantangan. Jakarta: Kesainc Blanc. Dikutip dari digilib.uin-suka.ac.id. Diakses tanggal tanggal 05 Januari 2020

Perpustakaan Universitas Lampung (2017). Buku Panduan Perpustakaan Universitas Lampung. Bandar Lampung: UPT Perpustakaan Unila 
Palimpsest: Journal of Information and Library Science Vol 12, Issue 2, (2021), page 110-110

Perpustakaan Universitas Lampung (2021). Dokumen Deskripsi Diri Akreditasi. Perpustakaan Universitas Lampung. Bandar Lampung: UPT Perpustakaan Unila.

Purwoko (2008). Perilaku Informasi Pemakai Perpustakaan di Perpustakaan Teknik Geologi Universitas Gadjah Mada.Yogyakarta. Dikutip dari digilib.uin-suka.ac.id. Diakses tanggal tanggal 06 Januari 2020

Wilson, T.D. (1999) "Models In Information Behaviour Research" Journal of Documentation, 55(3) 249-270. Dikutip dari digilib.uin-suka.ac.id. Diakses tanggal 05 Januari 2020 